\title{
Profile of VO2 max Student Athletes in West Java before Facing Multievent POPNAS in 2017
}

\author{
Gumelar Agusman Sarief*, Nuryadi Nuryadi \\ Sekolah Pascasarjana, Program Studi Pendidikan Olahraga \\ Universitas Pendidikan Indonesia \\ Bandung, Indonesia \\ *gumagusman@student.upi.edu
}

\begin{abstract}
The purpose of this study was to determine the profile of VO2 Max level in West Java student athletes. The research method used is descriptive quantitative with a survey approach. Data retrieval in this study using Test cooper $2.4 \mathrm{~km}$. The subjects of this study were West Java student athletes in $\mathbf{1 0}$ sports totaling 317 athletes (170 male athletes and 147 female athletes). Data analysis techniques use percentages. Based on the results of the study obtained the profile of $\mathrm{VO2}$ Max level athletes of male students in West Java in the very good category of $9.41 \%$, in the good category at $34.71 \%$, in the category of enough $35.29 \%$, in the category of less at $14.71 \%$, and in the category of very less at $5.88 \%$, while the VO2 Max level profile of West Java female student athletes in the very good category was $8.84 \%$, in the good category at $19.73 \%$, in the enough category at $43.54 \%$, in the less category at $\mathbf{1 8 . 3 7 \%}$, and in the very less category at $9.52 \%$. It can be concluded that the VO2 Max profile for all male and female students of West Java is enough.
\end{abstract}

Keywords—VO2 Max; student athletes; popnas

\section{INTRODUCTION}

In every sporting event, whether it's single event or multi event, an athlete must have excellent physical, technical, tactic and mental abilities so that what is the goal and achievement can be achieved maximally.

Good physical conditions will affect the functions and systems of the body's organisms, among others in the form of; 1) there will be an increase in the ability of the circulatory system and work of the heart, 2) there will be an increase in strength, flexibility, stamina and other physical components, 3) there will be a better movement economy during training, 4) there will be a faster recovery in body organs after exercise, 5) there will be a rapid response from our body's organisms if such response is needed at any time [1,2], in a more specific context in sports activities, the physical condition of a person will greatly influence even determine the movement of his appearance [2].

One component of physical ability, the component of endurance is a component of physical condition that is needed by an athlete, of several basic biomotor components, endurance can be developed first, because without resistance is difficult to hold repetition of other types of training. In line with this opinion that an athlete is required to achieve achievement, must have the ability to do exercises or matches with high intensity until complete without experiencing significant fatigue [2].

In the world of sports the term VO2 max is very familiar, many experts say that achievement in sports can be determined by the level of VO2 max, Physical capacity of athletes is an important element of success in sports achievements. It involves a huge number of different capacities, with aerobic capacity being its major component [3]. The higher the VO2max, the longer the ability of the muscles to do work means that the muscles do not get tired quickly, otherwise the lower the VO2max, the faster the ability of the muscles to do work, so that the muscles get tired. Thus it can be said that the high and low levels of a person's VO2 max can affect maximum achievement [4].

Pekan Olahraga Pelajar Nasional (POPNAS) is a multisport event between national students in Indonesia, and is a place to achieve achievement of student athletes throughout Indonesia, in the implementation of POPNAS XIV in 2017, sports were competed in 21 sports.

To achieve good achievement on the POPNAS multi event, a student athlete is required to have good physical condition because in reality the match is only a short time between 3-6 match days, so to be able to achieve maximum performance.

West Java Province is the most advanced province in terms of sports coaching, seen from several single events and multi event has always been the best province in terms of achievement, at the 2016 PON XIX multi event implementation West Java became the overall champion at the senior or elite multi event, as well Achievement of student athletes in the POPNAS XIII multi event in 2015 West Java Province became the overall champion of the multi event.

Facing the multi event level of POPNAS XIV students In 2017, West Java province again participated in the event by sending 336 athletes spread across 21 sports, with the best provinces in terms of achievement in the previous student multi event level in 2015, researchers interested in knowing with notes research entitled Profile Of Vo2max Student Athletes In West Java Before Facing Multi event POPNAS in 2017 so that knowing the profile of VO2max West Java student athletes can provide useful information for coaches, athletes and other policy makers. 


\section{METHOD}

The method used to collect data is a survey method with test and measurement techniques. This type of research used in this study is non-experimental research through descriptive quantitative approach, the instrument used is using a $2.4 \mathrm{Km}$ cooper test.

The subjects of this study were 317 athletes from West Java with age of 15-17 years old (170 male athletes and 147 female athletes) from 10 sports are; 1) Weightlifting, 2) Athletics, 3) Badminton, 4) Karate, 5) Archery, 6) Pencak Silat, 7) Swimming, 8) Sepak Takraw. 9) Taekwondo, 10) Tarung Derajat.

In this study data obtained in the form of numerical data or quantitative data. Simplification of data in this study was processed descriptively through percentages.

\section{RESUlTS AND DISCUSSION}

The sequences of calculation results will be adjusted to the procedures written in the section above. The results of data processing will be presented in detail as follows:

This research was carried out in West Java, which was addressed in the West Java Arcamanik Athletics field in West Java province, data collection was carried out on July 13, 2017. The subjects in this study were West Java student athletes facing POPNAS multi event in 2017 as many as 10 sports totaling 317 athletes male and female students aged 15-17 years. The study used $2.4 \mathrm{Km}$ cooper test.

Based on the results of research obtained from ten branches of male student athletes, 2 sports have an average profile of excellent $\mathrm{VO} 2$ max, 4 sports have an average profile of good $\mathrm{VO} 2$ max and 4 sports have an average profile of enough VO2 max, while female athletes 1 sport has an average profile of excellent VO2 max, 2 sports have an average profile of good $\mathrm{VO} 2$ max and 7 sports have an average profile of VO2 max is enough

For data analysis used in this study is to use descriptive percentages by using the results of the VO2 max profile determination criteria for male and female student athletes as contained in Table 1.

TABLE I. VO2 MAX MALE AND Female Profile CRITERIA

\begin{tabular}{|l|l|l|l|l|}
\hline No & \multicolumn{1}{|c|}{ Male } & \multicolumn{1}{c|}{ Female } & Score & \multicolumn{1}{c|}{ Category } \\
\hline 1 & $\geq 55.86$ & $\geq 47.99$ & 10 & Very Good \\
\hline 2 & $49.15-55.85$ & $42.39-47.98$ & 8 & Good \\
\hline 3 & $42.15-55.85$ & $36.79-42.38$ & 5 & Enough \\
\hline 4 & $35.74-42.44$ & $31.19-36.78$ & 4 & Less \\
\hline 5 & 35.73 & $\leq 31.18$ & 2 & Very Less \\
\hline
\end{tabular}


While the results of the study note that VO2 max for all female student athletes can be seen in Table 4.

TABLE IV. RECAPITULATION OF VO2 MAX RESUlts OF FEMALE STUDENTS

\begin{tabular}{|l|l|l|l|}
\hline No & \multicolumn{1}{|c|}{ Category } & \multicolumn{1}{|c|}{ Amount } & \multicolumn{1}{|c|}{ Percentage } \\
\hline 1 & Very Good & 14 & $9.52 \%$ \\
\hline 2 & Good & 27 & $18.37 \%$ \\
\hline 3 & Enough & 64 & $43.54 \%$ \\
\hline 4 & Less & 29 & $19.73 \%$ \\
\hline 5 & Very Less & 13 & $8.84 \%$ \\
\hline & Amount & 147 & $100 \%$ \\
\hline
\end{tabular}

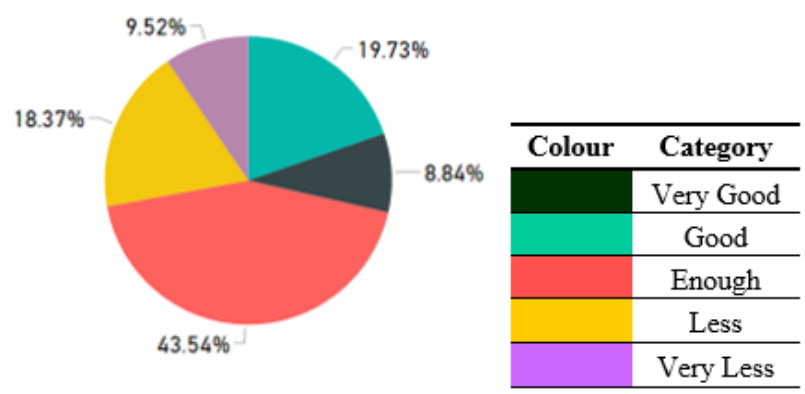

Based on Table 4 and figure 2, VO2 max data obtained from 147 female students there were $14(9.52 \%)$ female student athletes in the very poor category, 27 (18.37\%) female student athletes in the less category, $64(43.54 \%)$ female student athletes included in the category enough, $29(19.73 \%)$ female student athletes were in the good category, $13(8.84 \%)$ female student athletes were in the very good category from the results of the female student athlete's VO2 max will be elaborated on each sports branch VO2 max profile profiling male student athletes and female student athlates as contained in Table 5 and Table 6.

Fig. 2. VO2 max results of female student athletes.

TABle V. VO2 Max Profile CRiteria for Male Student Athletes

\begin{tabular}{|c|c|c|c|c|c|c|}
\hline \multirow{2}{*}{ No } & \multirow{2}{*}{ Sports } & \multicolumn{5}{|c|}{ MALE } \\
\hline & & $S K$ & $K$ & $C$ & $B$ & $S B$ \\
\hline 1 & Weightlifting & $\leq 32.17$ & $32.18-32.93$ & $32.94-33.69$ & $33.70-34.44$ & $\geq 34.45$ \\
\hline 2 & Athletics & $\leq 41.52$ & $41.53-46.78$ & $46.79-52.04$ & $52.03-57.30$ & $\geq 57.31$ \\
\hline 3 & Badminton & $\leq 51.87$ & $51.88-52.48$ & $52.49-53.10$ & $53.11-53.71$ & $\geq 53.72$ \\
\hline 4 & Karate & $\leq 37.03$ & $37.04-41.46$ & $41.47-45.90$ & $45.91-50.33$ & $\geq 50.34$ \\
\hline 5 & Archery & $\leq 32.55$ & $32.56-36.07$ & $36.08-39.59$ & $39.60-43.11$ & $\geq 43.12$ \\
\hline 6 & Pencak Silat & $\leq 40.57$ & $40.58-43.93$ & $43.94-47.28$ & $47.29-50.64$ & $\geq 50.65$ \\
\hline 7 & Swimming & $\leq 40.20$ & $40.21-43.92$ & $43.93-47.65$ & $47.66-51.38$ & $\geq 51.39$ \\
\hline 8 & Sepak Takraw & $\leq 38.18$ & $38.19-41.20$ & $41.21-44.22$ & $44.23-47.24$ & $\geq 47.25$ \\
\hline 9 & Taekwondo & $\leq 42.62$ & $42.63-45.93$ & $45.94-49.23$ & $49.24-52.54$ & $\geq 52.55$ \\
\hline 10 & Tarung Derajat & $\leq 44.55$ & $44.56-46.17$ & $46.18-47.80$ & $47.81-49.43$ & $\geq 49.44$ \\
\hline $\begin{array}{l}\mathrm{SK} \\
\mathrm{K} \\
\end{array}$ & $\begin{array}{l}\text { : Very Less } \\
\text { : Less }\end{array}$ & $\begin{array}{r}\mathrm{C} \\
\mathrm{B} \\
\end{array}$ & $\begin{array}{l}: \text { Enough } \\
: \text { Good }\end{array}$ & $\mathrm{SB}$ & : Very G & \\
\hline
\end{tabular}

TABLE VI. PROFILE CRITERIA FOR VO2 MAX FEMALE SPORTS ATHLETES

\begin{tabular}{|c|c|c|c|c|c|c|}
\hline \multirow{2}{*}{ No } & \multirow{2}{*}{ Sports } & \multicolumn{5}{|c|}{ FEMALE } \\
\hline & & $S K$ & $K$ & $C$ & $B$ & $S B$ \\
\hline 1 & Weightlifting & $\leq 28.00$ & $28.01-28.85$ & $28.86-29.70$ & $29.71-30.56$ & $\geq 30.57$ \\
\hline 2 & Athletics & $\leq 35.25$ & $35.26-39.83$ & $39.84-44.41$ & $44.42-48.99$ & $\geq 49.00$ \\
\hline 3 & Badminton & $\leq 40.55$ & $40.56-40.98$ & $40.99-41.41$ & $41.42-41.84$ & $\geq 41.85$ \\
\hline 4 & Karate & $\leq 35.33$ & $35.34-36.50$ & $36.51-37.67$ & $37.68-38.84$ & $\geq 38.85$ \\
\hline 5 & Archery & $\leq 28.86$ & $28.87-32.14$ & $32.15-35.42$ & $35.43-38.70$ & $\geq 38.71$ \\
\hline 6 & Pencak Silat & $\leq 32.16$ & $32.17-35.30$ & $35.31-38.45$ & $38.46-41.60$ & $\geq 41.61$ \\
\hline 7 & Swimming & $\leq 38.22$ & $38.23-39.99$ & $40.00-41.76$ & $41.77-43.53$ & $\geq 43.54$ \\
\hline 8 & Sepak Takraw & $\leq 32.27$ & $32.28-33.54$ & $33.55-34.81$ & $34.82-36.08$ & $\geq 36.09$ \\
\hline 9 & Taekwondo & $\leq 34.42$ & $34.43-38.03$ & $38.04-41.64$ & $41.65-45.26$ & $\geq 45.27$ \\
\hline 10 & Tarung Derajat & $\leq 36.24$ & $36.25-37.91$ & $37.92-39.58$ & $39.59-41.25$ & $\geq 41.26$ \\
\hline SK & : Very Less & & : Enough & & : Very & \\
\hline $\mathrm{K}$ & : Less & & : Good & & & \\
\hline
\end{tabular}




\section{CONCLUSION}

Based on the results of data processing, calculations, and analysis, it can be concluded that $\mathrm{VO} 2$ max profiles of West Java male student athletes aged 15-17 years are in the "Enough" category and the VO2max profile of West Java female student athletes aged 15-17 years is in the category " Enough".

\section{REFERENCES}

[1] Harsono, Coaching dan Aspek-Aspek Psikologis dalam Coaching. Jakarta: C.V. Tambak Kusuma, 1988.

[2] Kardjono, Modul Mata Kuliah Pembinaan Kondisi Fisik. Bandung: FPOK UPI, 2008,

[3] G. Rancovic, V. Mutavdzic, D. Taskic, A. Preljevic, M. Kocic and G.N Rancovic, "Aerobic capacity as an indicator in different kinds of sports," Bosnian J Of Basic Medical Sciences, vol. 10, no. 1, pp. 44-48, 2010.

[4] W. F. Ganong, Buku Ajar fisiologi kedokteran. Jakarta: EGC, 2001. 